\title{
REFLEXÕES SOBRE O ATIVISMO JUDICIAL
}

\author{
REFLECTIONS ON JUDICIAL ACTIVISM
}

\author{
Rocco Antonio Rangel Rosso Nelson* \\ Jackson Tavares da Silva de Medeiros ${ }^{\star \star}$
}

\begin{abstract}
RESUMO: O presente trabalho tem por escopo identificar o ativismo judicial na ótica do neoconstitucionalismo e na perspectiva hermenêutica, refletindo sobre os limites e possibilidades da jurisdição constitucional no Estado brasileiro. Para tanto, utilizar-se-á pesquisa qualitativa desenvolvida em base doutrinária, normativa e jurisprudencial. $\mathrm{O}$ tema vem suscitando discussões doutrinárias, jurisprudenciais e acadêmicas, em vários aspectos de abordagem, dada a sua relação fundamental com esferas temáticas teóricas que constituem pilastras mestras na construção e sustentação da democracia e do Estado Democrático de Direito. Por exemplo, há um liame cognitivo do tema com a análise de um novo Direito constitucional, da nova visão hermenêutica constitucional, da evolução e do papel do Estado, do princípio da tripartição dos poderes, do princípio da legalidade, da politização do judiciário, da judicialização da política e da democracia. Busca-se perpetrar esse trabalho à luz dessas razões.
\end{abstract}

Palavras-chave: Neoconstitucionalismo. Ativismo Judicial. Hermenêutica Constitucional.

\begin{abstract}
The present work has the purpose to identify the judicial activism in optical neoconstitutionalism and hermeneutic perspective, reflecting on the limits and possibilities of constitutional jurisdiction in the Brazilian state. To do so, it will use qualitative research conducted in doctrinal basis, case law and legislation. The issue has raised discussions doctrinal, jurisprudential and academic, on various aspects of approach, given its fundamental relationship with subject areas that constitute theoretical pillars master in building and sustaining democracy and the Rule of Law. For example, a bond with the subject 's cognitive analysis of a new constitutional law, constitutional hermeneutics of the new vision, evolution and the role of the state, the principle of tripartition of powers, the rule of law, the politicization of the judiciary, the judicialization of politics and democracy. Search to perpetrate this work in light of these reasons.
\end{abstract}

Keywords: Neoconstitutionalism. Judicial Activism. Constitutional Hermeneutics.

\footnotetext{
* Especialista em Direito e Cidadania pela Escola Superior do Ministério Público. Especialista em Direito Penal e Criminologia pela Universidade Potiguar. Mestre em Direito Constitucional pela UFRN. Ex-professor do curso de direito do Centro Universitário FACEX. Professor de Direito do Instituto Federal do Rio Grande do Norte IFRN, lotado no campus João Câmara. E-mail: rocconelson@ hotmail.com

** Bacharel em direito. Especialista em Direito Constitucional pela UFRN. Servidor público do Estado do Rio Grande do Norte. E-mail: jackamedeiros@ hotmail.com.

Versão em português recebida em 08/08/2014, aceita em 29/12/2014, e autorizada para publicação em $29 / 06 / 2015$
} 


\section{DAS CONSIDERAÇÕES INICIAIS}

Identificar o ativismo judicial como mecanismo de concretização da Constituição pela via hermenêutica, na conjuntura do neoconstitucionalismo, é o que se pretende no presente trabalho. Os limites e possibilidades da atividade jurisdicional, em primazia a jurisdição constitucional, exigem compreender o papel do Judiciário, na perspectiva da criação normativa, ao decidir o caso concreto.

Faz-se necessário situar a problemática no contexto da evolução do Estado, identificando as realidades sócio-jurídicas e as possibilidades e limites da atividade jurisdicional, na relação estabelecida entre o papel do Estado, o papel do Poder Judiciário e as demandas sociais.

É salutar, pois, perfilhar o elo entre a Constituição e a sociedade, apontando o mister da Lei Maior em sua relação de interdependência com a realidade social, a ascensão constitucional ao centro do ordenamento jurídico, o liame constitucional com valores, princípios e direitos fundamentais na ótica de uma constituição material.

Nessa senda, a realidade do ativismo judicial será analisada no prisma da jurisdição constitucional e na perspectiva do neoconstitucionalismo, de forma a propiciar reflexões que possibilitem a quebra de paradigmas e façam reluzir novos caminhos que trilhem rumo à concretização da democracia e da vontade constitucional, reavaliando-se os anacronismos doutrinários que representem, simplesmente, entraves frente à efetivação dos valores da Constituição e à realização democrática.

\section{OS REFLEXOS DO NEOCONSTITUCIONALISMO NO BRASIL}

Conforme Sarmento (2011, p.73), “O Direito brasileiro vem sofrendo mudanças profundas nos últimos tempos" estando estas mudanças, segundo o autor, "relacionadas à emergência de um novo paradigma tanto na teoria jurídica quanto na prática dos tribunais, que tem sido designado como "neoconstitucionalismo"".

\footnotetext{
${ }^{1}$ Sobre o neoconstitucionalismo, Uadi Lammêgo Bulos também chama de constitucionalismo contemporâneo, explicando que o fenômeno possui duas acepções distintas: "pela primeira, chama-se neoconstitucionalismo o modelo de Estado de Direito implantado com base em determinada forma de organização política. Expliquemos: durante muito tempo as correntes do pensamento constitucional andaram dissociadas. De um lado, os norteamericanos com a sua constituição garantista, de outro os europeus sem textos constitucionais garantistas. Pois bem, o neoconstitucionalismo propõe juntar essas duas vertentes, de modo a termos constituições normativas garantistas, dotadas de aperfeiçoado controle de constitucionalidade, para propiciarem ao Poder Judiciário maior segurança no equacionamento de conflitos. Nessa acepção, a idéia de neoconstitucionalismo assenta-se: (i) na Versão em português recebida em 08/08/2014, aceita em 29/12/2014, e autorizada para publicação em $29 / 06 / 2015$
} 
Três marcos são apontados, por Barroso (2007), para a observância de um novo direito constitucional: no marco histórico está, na Europa continental, “o constitucionalismo do pósguerra, especialmente na Alemanha e na Itália". No Brasil, por sua vez, assumiu tal papel "a Constituição de 1988 e o processo de redemocratização que ela ajudou a protagonizar”. Quanto ao marco filosófico, o autor diz ser este o pós-positivismo. Já o marco teórico, três grandes transformações o constitui, segundo o autor, quais sejam: "o reconhecimento de força normativa à Constituição", "a expansão da jurisdição constitucional” e "o desenvolvimento de uma nova dogmática da interpretação constitucional”.

Sarmento (2011, p. 73) elenca os fenômenos resultantes do neoconstitucionalismo que se relacionam com as mudanças ocorridas após a Constituição brasileira de 1988:

(a) reconhecimento da força normativa dos princípios jurídicos e valorização da sua
importância no processo de aplicação do Direito; (b) rejeição ao formalismo e
recurso mais freqüente a métodos ou "estilos" mais abertos de raciocínio jurídico:
ponderação, tópica, teorias da argumentação etc.; (c) constitucionalização do
Direito, com irradiação das normas e valores constitucionais, sobretudo os
relacionados aos direitos fundamentais, para todos os ramos do ordenamento; (d)
reaproximação entre o Direito e a Moral, com a penetração cada vez maior da
filosofia nos debates jurídicos; e (e) judicialização da política e das relações sociais,
com um significativo deslocamento de poder da esfera do Legislativo e do
Executivo para o Poder Judiciário.

É um contexto que permite entender a transposição de um Estado legislativo de direito, apegado aos formalismos do positivismo, para um Estado constitucional de direito, com aspectos pós-positivistas e neoconstitucionais.

Barroso (2011, p. 227), sobre Estado legislativo de direito, afirma que:

(...) Nele, a Constituição era compreendida, essencialmente, como um documento político, cujas normas não eram aplicáveis diretamente, ficando na dependência de desenvolvimento pelo legislador ou pelo administrador. Tampouco existia o controle de constitucionalidade das leis pelo Judiciário - ou, onde existia, era tímido e pouco relevante. Neste ambiente, vigorava a centralidade da lei e a supremacia do parlamento.

Já no tocante ao Estado constitucional de direito, elucida Barroso (2011, p. 227-228):

força vinculante das constituições; (ii) na supremacia constitucional diante do sistema de fontes do Direito; (iii) na eficácia e aplicabilidade integrais da carta magna; e (iv) na sobreinterpretaçãoconstitucional, de sorte a impedir a existência de espaços em branco, sujeitos à discricionariedade legislativa. Por mais político que um litígio se apresente, ele deve ser submetido a um controle de constitucionalidade imparcial e técnico." Já quanto à segunda acepção, discorre o autor: "denomina-se neoconstitucionalismo o conjunto de concepções oriundas de uma nova Teoria do Direito, a qual busca: (i) mais respeito a princípios, em vez de normas; (ii) mais ponderação do que subsunção; (iii) mais direito constitucional, em vez de conflitos jurídicos desnecessários; (iv) mais trabalho judicial, em vez de ficar esperando os legisladores cumprirem seu papel; e (v) mais valores, em lugar de dogmas e axiomas 'indiscutíveis"'. (BULOS, 2009, p. 22)

Versão em português recebida em 08/08/2014, aceita em 29/12/2014, e autorizada para publicação em 29/06/2015 
(...) a Constituição passa a valer como norma jurídica. A partir daí, ela não apenas disciplina o modo de produção das leis e atos normativos, como estabelece determinados limites para o seu conteúdo, além de impor deveres de atuação ao Estado. Nesse novo modelo, vigora a centralidade da Constituição e a supremacia judicial, como tal entendida a primazia de um tribunal constitucional ou suprema corte na interpretação final e vinculante das normas constitucionais.

Essa transformação do nível constitucional carrega sua essencialidade na busca pela efetivação dos direitos fundamentais. Por esse ângulo é que se pode compreender o protagonismo do Poder Judiciário, no exercício de uma jurisdição constitucional voltada, indispensavelmente, para a concretude da vontade da Lei Fundamental do Estado, primordialmente pelo exercício do controle de constitucionalidade.

É de se observar que "A função jurisdicional, por muito tempo, esteve atrelada tãosomente à idéia de simples reprodução do contido na lei a partir das doutrinas hermenêuticas do pensamento normativo ou sistemático" (SAMPAIO JÚNIOR, 2011, p. 404). Ocorre que a evolução da complexidade e tecnicidade social mostrou a necessidade de se reavaliar os métodos de aplicação do direito ao caso concreto apresentado em litígio.

O desenho constitucional que se apresenta, nessa perspectiva, é de um permissivo jurisdicional voltado para afirmação dos direitos fundamentais, com base em uma nova hermenêutica, permitindo ao juiz decidir, desde que de acordo com a Constituição, com carga valorativa, se assim for a essência do método de decisão por ele adotado.

O suporte básico para tal fim recai na força normativa da Constituição e na constitucionalização do direito, pois que a incidência da Lei Fundamental é que permitirá e limitará a atuação de quaisquer Poderes estatais, dentre eles o Judiciário. Mister, portanto, quebrar paradigmas para que se alcance, em verdade, um Estado Democrático de Direito, com uma atuação ativista do Judiciário, quando for necessária e legitimamente constitucional.

\subsection{A CONSTITUCIONALIZAÇÃO DO DIREITO E DAS LEIS INFRACONSTITUCIONAIS}

A constitucionalização do direito pode ser "associada a um efeito expansivo das normas constitucionais, cujo conteúdo material e axiológico irradia, com força normativa, por todo o sistema jurídico". (BARROSO, 2011, p. 12)²

\footnotetext{
${ }^{2}$ Luis Roberto Barros lembra que "A Locução constitucionalização do Direito é de uso relativamente recente na terminologia jurídica e, além disso, comporta múltiplos sentidos. Por ela se poderia pretender caracterizar, por exemplo, qualquer ordenamento jurídico no qual vigorasse uma Constituição dotada de supremacia. Como este é Versão em português recebida em 08/08/2014, aceita em 29/12/2014, e autorizada para publicação em $29 / 06 / 2015$
} 
O que se percebe é que a constitucionalização do direito não se restringe à inclusão de diversos temas de relevância jurídica no texto constitucional, pois que, transcendendo essa idéia, a Constituição passa a exigir o que a doutrina denomina de filtragem constitucional do direito, que, para Barroso (2011, p. 20), “consiste em que toda a ordem jurídica deve ser lida e apreendida sob a lente da Constituição, de modo a realizar os valores nela consagrados”.

Esse redimensionamento constitucional, com uma Constituição pautada em valores e princípios, além de regras, passa a exigir a compatibilidade das leis com a norma constitucional instituída, não apenas no aspecto formal, mas também material. Assim aduz Moncada (2002, p. 87):

Ora a revalorização da Constituição como ordem material de valores implica necessariamente um conceito de lei em sentido axiológico-material, por muito lato e indefinido que possa parecer (...). Material porque subordinado à ordem material de valores da Constituição sob pena de inconstitucionalidade a censurar pelos órgãos competentes, os Tribunais. Se os predicados da razão e da virtude já não vivem apenas da especulação dos juristas e passaram a ser reduzidos a escrito no texto constitucional ou seja, se o texto agora não é o encontrado pela razão abstracta mas o texto escrito de uma norma constitucional, a lei fica impregnada da ordem constitucionalmente assinalada. O novo conceito material da lei é um conceito constitucional, não apenas especulativo. Houve que transportar para o exercício do poder legislativo algumas características matérias constitucionais que o pensamento moderno lhe não assinalou, salvo raras excepções, como se viu, cego pela crença algo ingénua de que correspondendo a lei ao exercício da razão dela não poderia vir mal ao mundo. Houve que constitucionalizar, portanto, aquilo que a modernidade menos constitucionalizou, o poder legislativo (...).

Por esse ângulo, é notório que na sistemática da constitucionalização do direito, que ressoa como característica do fenômeno neoconstitucionalista, a força normativa da Constituição reverbera sobre o processo de produção normativa e sobre as leis, de forma que a lei cede espaço de protagonista do sistema jurídico para a norma constitucional.

De acordo com Callejón (apud PEREIRA, 2006, p. 120),

\footnotetext{
La Constitución ocupa una posición central en el ordenamiento jurídico, en virtud de la cual puede decirse que la relación entre Constituición y normas infraconstitucionales no es de mera jerarquía sino de supremacía. Esta diferenciación nos manifesta cómo, además de su condición jerárquicamante superior sobre el resto de las normas, la constituición desarrolla una función de irradiación sobre el resto del ordenamiento jurídico. ${ }^{3}$
}

um traço comum de grande número de sistemas jurídicos contemporâneos, faltaria especificidade à expressão. (...) Poderia ela servir para identificar, ademais, o fato de a Constituição formal incorporar em seu texto inúmeros temas afetos aos ramos infraconstitucionais do Direito. Trata-se de fenômeno iniciado, de certa forma, com a Constituição portuguesa de 1976, continuando pela Constituição espanhola de 1978 e levado ao extremo pela Constituição brasileira de 1988...”. (BARROSO, 2011, p.12).

${ }^{3}$ A constituição ocupa uma posição central no ordenamento jurídico, em virtude da qual pode se dizer que a relação entre Constituição e normas infraconstitucionais não é de mera hierarquia, mas de supremacia. Essa Versão em português recebida em 08/08/2014, aceita em 29/12/2014, e autorizada para publicação em 29/06/2015 
Toda essa proteção constitucional reflete na limitação de partes específicas do sistema jurídico-normativo ao que determina a Carta Magna, o que faz limitar a produção de leis pelo Legislativo e a interpretação constitucional pelo Judiciário aos ditames constitucionais.

Para Moreira (apud CAMBI, 2009, p. 58) "o alargamento do espaço constitucional se deu a partir da constitucionalização dos direitos infraconstitucionais que, por sua vez, ampliou a extensão e a intensidade da vinculação constitucional do legislador ordinário". "A vinculação da atividade legislativa é essencial não só para a proteção dos direitos fundamentais, como também para a concretização destes em inúmeras hipóteses”. (MENDES, 1999, p. 214)

A Constituição, "em razão de se colocar em um nível normativo hierarquicamente superior à legislação ordinária (princípio da supremacia da Constituição), acaba por prever um conjunto de direitos (fundamentais) que as leis não podem derrogar”. (CAMBI, 2009, p. 58)

Segundo Agra (2008, p. 436),

\begin{abstract}
Essa revisitação do fenômeno constitucional parte do pressuposto da reafirmação da força normativa da Constituição e sua consequente densificação. Assim, com seu fortalecimento, em que a imperatividade de suas normas atinge todas as searas do direito, surge uma legalidade superior à legalidade ordinária, deslocando a primazia do legislador infraconstitucional para o cumprimento da vontade do sujeito constituinte, composto de forma plural pelos mais variados segmentos da sociedade.
\end{abstract}

Essa nova realidade, portanto, está pautada na rematerialização da Constituição, havendo uma expansão da proteção constitucional aos direitos fundamentais e adoção de diretrizes para os poderes públicos. Isto posto, nota-se a transcendência do papel constitucional à mera limitação de Poderes, de forma que o conteúdo constitucional se expande e a força normatividade da Constituição irradia para limitar todo o ordenamento jurídico infraconstitucional e para exigir a concretização de direitos fundamentais.

\title{
2.1.1 Os Direitos Fundamentais na Constituição Brasileira de 1988
}

Com a Constituição da República Brasileira de 1988, que veio iluminar o processo de redemocratização do Estado Brasileiro, após o longo período de Regime Militar, o direito constitucional ganhou nova roupagem. Constituiu-se uma nova forma de pensar a 
Constituição. Ela deixa de ser apenas técnica jurídica e passa a refletir conteúdo axiológico, cujo alicerce recai na dignidade humana, rodeada de direitos fundamentais.

Os direitos fundamentais lograram sentido distinto a eles outorgados pela Constituição de 1988, que os gravaram com "cláusula de imutabilidade ou com a garantia de eternidade", o que permite a declaração de inconstitucionalidade de emenda constitucional tendentes a aboli-los, pelo Pode Judiciário (MENDES, 1999, p. 36).

Para Agra (2008, p. 439),

\begin{abstract}
A instituição da Constituição Cidadã, de 1988, pródiga em direitos, fez com que a prestação jurisdicional abrangesse segmentos sociais até então excluídos, obrigando um desenvolvimento da teorética constitucional para que essas prerrogativas pudessem transpor sua seara retórica para uma seara fática. A existência de direitos fundamentais apenas no plano da validade jurídica não mais satisfazia a real necessidade de segmentos hipossuficientes da sociedade.
\end{abstract}

Tamanha é a necessidade da relação da Constituição com os direitos fundamentais, que a expressão do art. 16 da Declaração dos Direitos do Homem e do Cidadão, de 1789, revela que "toda sociedade em que a garantia dos direitos não está assegurada, nem a separação dos poderes está determinada, não tem Constituição". Esse é o motivo que leva Ferreira Filho (2003, p. 244) a afirmar:

\begin{abstract}
A Constituição é apenas aquela que serve à limitação do poder e enseja o governo moderado estabelecido com base na separação de poderes. Não é Constituição qualquer arranjo político, mas somente aquela que cumpre essa finalidade de garantia, de garantia da liberdade, de garantia de direitos fundamentais. Assim, a doutrina dos direitos fundamentais explicita a própria finalidade da Constituição. Destarte, o reconhecimento dos direitos fundamentais é a própria base do Estado.
\end{abstract}

Para Hesse (apud BONAVIDES, 2008, p. 560) “criar e manter os pressupostos elementares de uma vida na liberdade humana, eis aquilo que os direitos fundamentais almejam". Por outro lado, explica Bonavides (2008, p. 560), apoiando-se em Konrad Hesse, que há uma concepção "mais restrita, mais específica e mais normativa, a saber: direitos fundamentais são aqueles direitos que o direito vigente qualifica como tais".

A perspectiva meramente subjetiva dos direitos fundamentais, vigente durante o constitucionalismo do Estado Liberal, é complementada por uma nova visão que se diz objetiva. De acordo com Sarmento (2003, p. 252), era subjetiva, "pois cuidava-se apenas de identificar quais prestações o indivíduo poderia exigir do Estado em razão de um direito positivado na sua ordem jurídica"; já a dimensão objetiva, explica o referido autor que ela se encontra ligada ao reconhecimento de que os direitos fundamentais "além de imporem certas Versão em português recebida em 08/08/2014, aceita em 29/12/2014, e autorizada para publicação em $29 / 06 / 2015$ 
prestações aos poderes estatais, consagram também os valores mais importantes em uma comunidade política, constituindo, como afirmou Konrad Hesse, 'as bases da ordem jurídica da coletividade"”.

Nesse prisma, nota-se a importância dos direitos fundamentais na Constituição Federal brasileira de 1988, tanto dando suporte jurídico-axiológico para a afirmação de uma Constituição materialmente exigível, quanto estabelecendo limitação formal que não apenas permite restringir a atuação dos poderes estatais, mas também possibilita que o cidadão possa exigir do Estado a concretização dos direitos. Ou seja, os direitos fundamentais constituem o núcleo da força normativa da Constituição.

\title{
2.2 FORÇA NORMATIVA DA CONSTITUIÇÃO, DINAMISMO SOCIAL E DINAMISMO CONSTITUCIONAL
}

No Brasil, as discussões sobre a força normativa da Constituição só se deram, de forma consistente, no decorrer da década de 1980, cabendo à Constituição de 1988 e à doutrina e jurisprudência que se desenvolvia após a promulgação da mesma, "o mérito elevado de romper com a posição mais retrógrada”. (BARROSO, 2011, p. 5-6) ${ }^{4}$

De acordo com Hesse (1991, p. 19),

\begin{abstract}
Embora a Constituição não possa, por si só, realizar nada, ela pode impor tarefas. A Constituição transforma-se em força ativa se essas tarefas forem efetivamente realizadas, se existir a disposição de orientar a própria conduta segundo a ordem nela estabelecida, se, a despeito de todos os questionamentos e reservas provenientes dos juízos de conveniência, se puder identificar a vontade de concretizar essa ordem.
\end{abstract}

Hesse (1991, p. 16-17) explica que a pretensão de eficácia da Constituição jurídica “apresenta-se como elemento autônomo no campo de forças de qual resulta a realidade do Estado. E que "a Constituição adquire força normativa na medida em que logra realizar essa pretensão de eficácia”.

\footnotetext{
${ }^{4}$ Barroso (2011, p. 5-6) explica que "Uma das mudanças de paradigma ocorridas ao longo do século XX foi a atribuição à norma constitucional do status de norma jurídica. Superou-se, assim, o modelo que vigorou na Europa até meados do século passado, no qual a Constituição era vista como um documento essencialmente político, um convite à atuação dos Poderes Públicos. A concretização de suas propostas ficava invariavelmente condicionada à liberdade de conformação do legislador ou à discricionariedade do administrador. Ao Judiciário não se reconhecia qualquer papel relevante na realização do conteúdo da Constituição. Com a reconstitucionalização que sobreveio à 2a. Guerra Mundial, este quadro começou a ser alterado. (...) Atualmente, passou a ser premissa do estudo da Constituição o reconhecimento de sua força normativa, do caráter vinculativo e obrigatório de suas disposições. Vale dizer: as normas constitucionais são dotadas de imperatividade, que é o atributo de todas as normas jurídicas, e sua inobservância há de deflagrar os mecanismos próprios de coação, de cumprimento forçado".

Versão em português recebida em 08/08/2014, aceita em 29/12/2014, e autorizada para publicação em 29/06/2015
} 
É de se ressaltar que não se pode dissociar a realidade constitucional da realidade social, de forma que a força normativa da Constituição está relacionada à força dos fatores sociais que se apresentam e requerem ser normatizados. Conforme Bastos (2002, p. 246), "não se separam as normas da realidade fática na qual pretendam incidir".

Sobre essa relação estabelecida entre a dinamicidade social e a dinamicidade constitucional, afirma Justen Filho (2002, p. 288-289):

(...) há um fenômeno de interação entre o meio social e a constituição, com efeitos reflexos e permanentes. Uma constituição influencia e determina a organização social, mas a sociedade também vivencia as normas constitucionais (que produz) de modos variáveis e dinâmicos. Por isso, o texto constitucional comporta diferentes interpretações e, ao longo da trajetória de um povo, vão-se alterando as concepções jurídicas acerca do significado e extensão das normas (e, mesmo, princípios) constitucionais. A dinamicidade dos processos sociais se reflete sobre a constituição, de modo que as inovações vivenciadas ao interno da sociedade são influenciadas pela disciplina jurídica, mas também se refletem sobre o Direito, mesmo sobre aquele pré-existente.

Para Hesse (1991, p. 13), “o significado da ordenação jurídica na realidade e em face dela somente pode ser apreciado se ambas - ordenação e realidade - forem consideradas em sua relação, em seu inseparável contexto, e no seu condicionamento recíproco". Continua Hesse (1991, p. 13) explicando:

\footnotetext{
Uma análise isolada, unilateral, que leve em conta apenas um ou outro aspecto, não se afigura em condições de fornecer resposta adequada à questão. Para aquele que contempla apenas a ordenação jurídica, a norma "está em vigor" ou "está derrogada"; Não há outra possibilidade. Por outro lado, quem considera, exclusivamente, a realidade política e social ou não consegue perceber o problema na sua totalidade, ou será levado a ignorar, simplesmente, o significado da ordenação jurídica.
}

Segundo Justen Filho (2002, p. 289), “toda Constituição é um conjunto de princípios e regras cuja extensão e conteúdo apresentam natureza dinâmica”. E continua o autor (JUSTEN FILHO, 2002, p. 289) a dizer que "se a constituição permanecesse inalterada, cristalizada segundo a conformação do momento original, haveria uma dissociação entre direito e sociedade, que não é apenas indesejável, mas é impossível”.

Dessa forma, o Direito não pode ser estático, porque estática não é a sociedade. Por consequiência, a Constituição deve acompanhar a evolução social, sendo esse o contexto que permite maior atuação da jurisdição constitucional, pois que, nem sempre, o problema social 
que se apresenta encontra solução no texto formal, exigindo uma aplicação jurídica e hermenêutica compatível com a realidade apresentada. ${ }^{5}$

Conforme Garcia-Pelayo (1957, p. 132),

Toda constitución, rígida o flexible, supone un intento de solución al aspecto jurídico-político de la existencia estatal, solución que se toma de acuerdo com unos datos del problema (situación de poderes sociales, estructura económica, estado cultural, etc.); mas cuando estos datos cambiam, es claro que si la constitución quiere seguir resolviendo el problema de la convivencia há de cambiar, con reforma o sin reforma formal, el sentido se sus preceptos; pero, justamente, la esencia de una constitución no radica, sin más, en unas palabras, sino en el significado atribuído a las palabras del texto com relación a las situaciones concretas. Por eso, una constitución, escrita o no escrita, no es nunca una obra totalmente acabada, sino una apertura de possibilidades para que los hombres realicen su convivencia(... ${ }^{6}$.

Hesse (1991, p. 20-21), por sua vez, afirma que

\begin{abstract}
A força que constitui a essência e a eficácia da Constituição reside na natureza das coisas, impulsionado-a, conduzindo-a e transformando-se, assim, em força ativa. Como demonstrado, daí decorrem os seus limites. Daí resultam também os pressupostos que permitem à Constituição desenvolver de forma ótima a sua força normativa. Esses pressupostos referem-se tanto ao conteúdo da Constituição quanto à práxis constitucional. Tentarei enunciar, de forma resumida, alguns desses requisitos mais importantes.

a) Quanto mais o conteúdo de uma Constituição lograr corresponder à natureza singular do presente, tanto mais seguro há de ser o desenvolvimento de sua força normativa.

(...)

b) Um ótimo desenvolvimento da força normativa da Constituição depende não apenas do seu conteúdo, mas também de sua práxis. De todos os partícipes da vida constitucional, exige-se partilhar aquela concepção anteriormente por mim denominada vontade de Constituição (WillezurVerfassung). Ela é fundamental, considerada global ou singularmente.
\end{abstract}

O que não se pode pensar, por tudo isso, é que a Constituição deva ser a todo tempo alterada. A dinamicidade constitucional, como se percebe, é necessária, todavia não há como a Constituição ser alterada no compasso acelerado no qual se transforma a sociedade, sob

\footnotetext{
${ }^{5}$ Nota-se que "O Direito tem de acompanhar a evolução dos processos sociais, os quais podem, inclusive, configurar-se como dotados de outras características e riquezas não previstos no modelo normativo formal". (JUSTEN FILHO, 2002, p. 289).

${ }^{6}$ Toda Constituição, rígida ou flexível, supõe a intenção de solucionar o aspecto jurídico-político da existência estatal, solução que se toma de acordo com dados do problema (situações de poderes sociais, estrutura econômica, estado cultural, etc, etc.); mas quando estes dados mudam, é claro que se a Constituição quiser seguir resolvendo o problema da convivência há de mudar, com reforma ou sem reforma formal, o sentido de seus preceitos; mas, justamente, a essência de uma Constituição não reside, sem mais, em umas palavras, senão no significado atribuído às palavras do texto com relação às situações concretas. Por isso, uma Constituição escrita ou não escrita, não é uma obra totalmente acabada, e sim uma abertura de possibilidades para que os homens realizem sua convivência. (Tradução livre)

Versão em português recebida em 08/08/2014, aceita em 29/12/2014, e autorizada para publicação em $29 / 06 / 2015$
} 
pena de se perder a própria essência constitucional e de se gerar profunda insegurança jurídica.

Justen Filho (2002, p. 290) aponta dois efeitos que seriam inadmissíveis em face desse contexto: "Uma variável seria a eliminação da natureza normativa da Constituição. Se a modificação das vivências sociais produzir automática alteração da disciplina jurídica, o resultado será a eliminação da função normativa". Continua o autor: "outro risco seria a destruição da natureza axiológica e democrática do Direito". Explicando que "num cenário como esse, em que a dinâmica dos fatos prevalece sobre a força normativa do direito, o único critério para diferenciar licitude e ilicitude seria a opção da maioria”.

Segundo Hesse (1991, p. 22), “a tendência para a frequente revisão constitucional sob a alegação de suposta e inarredável necessidade política" é "perigosa para a força normativa da Constituição". Ele explica que "cada reforma constitucional expressa a idéia de que, efetiva ou aparentemente, atribui-se maior valor às exigências de índole fática do que à ordem normativa vigente". Daí os precedentes gerarem preocupação. A constância de reformas na Constituição debilita a sua força normativa e "a estabilidade constitui condição fundamental da eficácia da Constituição".

\subsection{O CONSTITUCIONALISMO PRINCIPIOLÓGICO}

Com o advento do Estado Democrático de Direito e da concepção pós-positivista do Direito, observou-se um ganho de normatividade por parte dos princípios. A relação entre princípios e Constituição tornou-se pressuposto de essencialidade da norma constitucional. “(...) a constitucionalização dos princípios compreende duas fases distintas: a fase programática e a fase não programática, de concreção e objetividade”. (BONAVIDES, 2008, p. 274)

A fase programática configura uma mínima normatividade constitucional principiológica, caracterizando-se pela abstrativização e "aplicabilidade diferida". Na fase não programática, a aplicabilidade é direta e imediata, revelando, "de imediato a sua dimensão objetiva e concretizadora". (BONAVIDES, 2008, p. 274)

Observa Bonavides ( 2008, p. 258-259) que

O exame teórico da juridicidade dos princípios constitucionais é indissociável de uma prévia indagação acerca da eficácia normativa dos princípios gerais de Direito

\footnotetext{
${ }^{7}$ A expressão foi copiada de Streck ( 2009, p. 109; 2008, p. 298). Explica este autor que o constitucionalismo principiológico foi introduzido pelo Estado Democrático de Direito.

Versão em português recebida em 08/08/2014, aceita em 29/12/2014, e autorizada para publicação em 29/06/2015
} 
cujo ingresso na Constituição se faz com força positiva incontrastável, perdendo, desde já, grande parte daquela clássica e alegada indeterminação, habitualmente invocada para retirar-lhes o sentido normativo de cláusulas operacionais.

A inserção constitucional dos princípios ultrapassa, de último, a fase hermenêutica das chamadas normas programáticas. Eles operam nos textos constitucionais da segunda metade deste século uma revolução de juridicidade sem precedente nos anais do constitucionalismo. De princípios gerais se transformaram, já, em princípios constitucionais. ${ }^{8}$

Valendo-se dos ensinamentos de Konrad Hesse, Bastos (2002, p. 223-224) anota que os princípios constitucionais constituem "metas que podem e devem entrar a qualquer momento no discurso legitimador do Direito", cabendo a eles "a missão de orientar e coordenar os diferentes dados e fatores que concorrem na interpretação constitucional".

Com o pós-positivismo, que pode ser identificado nas décadas finais do século XX, constatou-se acentuação da "hegemonia axiológica dos princípios" pelas novas Constituições que eram promulgadas, convertendo-os "em pedestal normativo sobre o qual assenta todo o edifício jurídico dos novos sistemas constitucionais”. (BONAVIDES, 2008, p. 264)

A confirmação da normatividade dos princípios os fizeram ser colocados no sistema jurídico com hegemonia na construção normativa, de maneira que passaram centralidade da norma constitucional, como regentes da ordem jurídica. "Os princípios são, pois, as vigas mestras do texto constitucional”. (BASTOS, 2002, p. 229)

No dizer de Bonavides (2008, p. 258-259), é mais e mais manifesta a "importância vital" a qual os princípios ostentam na ordem jurídica, "sobretudo se lhes examinarmos a função e presença no corpo das Constituições contemporâneas," onde vão estar presentes "como os pontos axiológicos de mais alto destaque e prestígio com que fundamentar na Hermenêutica dos tribunais a legitimidade dos preceitos da ordem constitucionais".

Pensar uma nova hermenêutica, portanto, é necessário para a aplicação da norma principiológica por meio, principalmente, da jurisdição constitucional. Os critérios utilizados para soluções de conflitos envolvendo apenas regras já não o são suficientes para a solução de caso de cunho material e valorativo. Isso leva à constatação de que o modelo de jurisdição

\footnotetext{
${ }^{8}$ Streck (2009, p. 109-110) explica que "com o advento do constitucionalismo principiológico, não há mais que falar em 'princípios gerais dos Direitos', pela simples razão de que foram introduzidos no Direito como um 'critério positivista de fechamento do sistema', visando a preservar, assim, a 'pureza e a integridade' do mundo de regras. Nesse sentido, basta observar algumas questões que, pelo seu valor simbólico, representam o modo pelo qual a instituição 'positivismo' assegura a sua validade mesmo em face da emergência de um novo paradigma. É o caso de três dispositivos elementos de resistência no interior do sistema jurídico, como que para demonstrar a prevalência do velho em face do novo".

Versão em português recebida em 08/08/2014, aceita em 29/12/2014, e autorizada para publicação em $29 / 06 / 2015$
} 
insculpido no Estado Liberal também restou superado, já que incompatível com as requisições da Constituição principiológica. ${ }^{9}$

Conforme Cambi (2009, p. 87), de forma diversa do paradigma positivista, no qual, aos princípios jurídicos restava ocupar um patamar secundarista e acessório, a Constituição passa a se firmar "como uma ordem objetiva de valores ou um sistema aberto de princípios $e$ de regras", de maneira que os princípios passam a ser "reconhecidos como pilares axiológicos do sistema jurídico e, conseqüentemente" a possuírem "força normativa imediata". Os princípios agora "são fontes primárias do direito, subjacentes às regras, expressando juridicamente os valores e os fins de uma sociedade”.

O abraço constitucional aos princípios, nessa senda, reluz inseparável, como fortalecimento da proteção dos direitos fundamentais, dos valores constitucionais, da democracia e da própria força normativa da Constituição. A materialidade e a carga valorativa dos princípios constitucionais ressoam a própria materialidade e o próprio valor da Carta Magna.

\section{A JURISDIÇÃO CONSTITUCIONAL BRASILEIRA E O ATIVISMO JUDICIAL}

Com o redimensionamento da Constituição, percebeu-se a expansão da jurisdição constitucional como forma de realizar os direitos fundamentais nela insculpidos. "As referências à Teoria Geral da Jurisdição Constitucional (...) têm crescido (...) propiciando as grandes discussões sobre direitos fundamentais e a evolução de sua aplicabilidade jurisprudencial". (BARACHO, 2003, p. 1)

Em síntese, jurisdição constitucional pode ser compreendida pelo exercício do poder conferido a juízes e tribunais para aplicar a Constituição de forma direta, para desempenhar o controle de constitucionalidade das leis e dos atos do Poder Público em geral e para a realização de interpretação conforme a Constituição do ordenamento infraconstitucional. (BARROSO, 2011, p. 228)

\footnotetext{
${ }^{9}$ Segundo Marinoni (2007, p. 49), "Na linha do positivismo clássico, não é possível aceitar que o juiz possa aplicar uma norma que não se revele mediante o seu próprio texto e que, ao contrário, exija do intérprete margem de subjetividade para a definição do seu significado. A aplicação ou a declaração da regra, própria da jurisdição daquela época, não se concilia com a atribuição de significado que caracteriza a metodologia dos princípios.O positivismo clássico, temendo que os princípios pudessem provocar uma profunda imprevisibilidade em relação às decisões judiciais - o que também acarretaria incerteza quanto ao significado do direito -, concluiu que a atividade com os princípios deveria ser reservada a um órgão político, já que não se amoldava com a função que era esperada do juiz, isto é, com a simples aplicação do ditado da regra produzida e acabada pelo legislativo". Versão em português recebida em 08/08/2014, aceita em 29/12/2014, e autorizada para publicação em 29/06/2015
} 
De acordo com Baracho (2003, p. 3), definir a jurisdição constitucional, em seu âmbito material, faz-se em termos bem amplos, resguardando sua imparcialidade, vinculação ao dinamismo social, estabelecendo-se como órgão que atue e delibere de forma estritamente judicial, sem prejudicar a relevância política do que se decide. "Como órgão da Constituição, transforma-se em norma viva, garante da livre e pacífica convivência e instrumento de transformação social”.

A perspectiva neoconstitucional aponta a existência de uma jurisdição constitucional em expansão para concretização da vontade da Constituição e a conseqüente realização dos direitos fundamentais, por meio da hermenêutica e da aplicação da norma constitucional. "Em sentido amplo, a jurisdição constitucional envolve a interpretação e aplicação da Constituição, tendo como uma das principais expressões o controle de constitucionalidade das leis e atos normativos". (BARROSO, 2007, p. 35-36)

Estabelecendo essa relação da jurisdição constitucional com os direitos fundamentais, Agra (2008, p. 442-443) aborda a temática da seguinte forma:

\begin{abstract}
Os direitos fundamentais se estabelecem como os mais importantes elementos para a configuração do neoconstitucionalismo. Quando o processo de expansão da atuação da jurisdição constitucional se ampara sobre seus fundamentos, até mesmo as decisões que incidem em controversas searas políticas encontram respaldo na sociedade, desempenhando o órgão que exerce a jurisdição constitucional um papel de guardião dos direitos agasalhados pela Constituição. No atendimento das demandas sociais pós-modernas, a jurisdição é chamada a incidir cada vez de forma mais constante na seara política, chegando, inclusive, a desempenhar uma função normogenética, quando um direito fundamental não puder ser exercido por falta de regulamentação do legislador infraconstitucional.
\end{abstract}

Nesse sentido, percebe-se que a jurisdição constitucional, pautada em direitos fundamentais, não pode mais ficar restrita aos formalismos jurídicos no poder de decidir. É dizer, a partir do momento em que se tem a Constituição como parâmetro para todo o ordenamento jurídico, a filtragem constitucional se faz necessária e a forma de realizá-la é a jurisdição constitucional.

Com as exigências da sociedade, frente ao Estado, para a concretização dos direitos fundamentais, mormente quando se alcança o Estado Democrático de Direito, e a omissão e inércia dos Poderes Legislativo e Executivo, os cidadãos procuraram o Poder Judiciário, a fim de terem esses direitos realizados.

Ademais, como esses direitos fundamentais foram constitucionalizados, constituindo o cerne da Constituição, que, por sua vez, ganhou prestígio e força normativa, a tutela 
jurisdicional a tais direitos consubstancia-se como pressuposto da realização da democracia e do Estado Democrático de Direito.

E, se cabe ao Poder Judiciário (Supremo Tribunal Federal) proteger a Constituição, também cabe a ele dar guarida aos direitos fundamentais. Por isso, a necessidade de repensar a sistemática jurídica da tripartição de poderes, de modo que o ativismo judicial e a judicialização da política sejam vistos como democraticamente legítimos, no compasso harmônico de uma nova hermenêutica e de um novo constitucionalismo neoconstitucionalismo.

\subsection{A HERMENÊUTICA CONSTITUCIONAL COMO MECANISMO DE CONCRETIZAÇÃO E GARANTIA DE DIREITOS FUNDAMENTAIS}

No contexto que aqui se apresentam, os direitos fundamentais precisam ser efetivados como forma de concretizar a vontade da Constituição e realizar os fins do Estado Democrático de Direito, com base em princípios e valores. Para tanto, resta patente a insuficiência dos métodos adotados pelo Estado Liberal nos moldes do positivismo jurídico. ${ }^{10}$

Nesse sentido, a expansão da jurisdição constitucional vem exigir uma nova hermenêutica, uma hermenêutica constitucional, com métodos capazes de atender à solução de casos que envolvam princípios e valores. Esses princípios e valores "representam, por conseguinte, a matéria prima da Nova Hermenêutica; esta, outra coisa não é senão a própria teoria material da Constituição". (BONAVIDES, 2008, p. 597)

Conforme Pereira (2006, p. 120), a hermenêutica constitucional permite ser imaginada pela denominação de lócus hermenêutico, sendo esse o sentido que aqui se tem dado a ela. É dizer, "lugar a partir do qual há uma conformação das possibilidades de sentido de todas as normas inferiores, não tendo como, pois, compreender, interpretar e aplicar o Direito independentemente do padrão constitucional".

Para a realização dessa nova hermenêutica, as possibilidades de atuação do Poder Judiciário se alargam, promovendo resultados cujo fim seja a melhor aplicação dos direitos

10 Conforme Bonavides (2008, p. 596), "Toda interpretação dos direitos fundamentais vincula-se, de necessidade, a uma teoria dos direitos fundamentais; esta, por sua vez, a uma teoria da Constituição, e ambas - a teoria dos direitos fundamentais e a teoria da Constituição - a uma indeclinável concepção do Estado, da Constituição e da cidadania, consubstanciando uma ideologia, sem a qual aquelas doutrinas, em seu sentido político, jurídico e social mais profundo, ficariam de todo ininteligíveis. De tal concepção brota a contextura teórica que faz a legitimidade da Constituição e dos direitos fundamentais, traduzida numa tábua de valores da ordem democrática do Estado de Direito onde jaz a eficácia das regras constitucionais e repousa a estabilidade de princípios do ordenamento jurídico, regido por uma teoria material da Constituição".

Versão em português recebida em 08/08/2014, aceita em 29/12/2014, e autorizada para publicação em 29/06/2015 
fundamentais, princípios e valores que venham a colidir. As técnicas de interpretação, primordialmente as utilizadas pelo Supremo Tribunal Federal, refletem, dessa forma, a exigência constitucional e social de concretização dos direitos fundamentais, no contexto da realidade social e da força normativa da Constituição.

De acordo com Hesse (1991, p. 16),

(...) a interpretação tem significado decisivo para a consolidação e preservação da força normativa da Constituição. A interpretação constitucional está submetida ao princípio da ótima concretização da norma. (Gebotoptlimaler Verwirklichung der Norm). Evidentemente, esse princípio não pode ser aplicado com base nos meios fornecidos pela subsunção lógica e pela construção conceitual. Se o direito e, sobretudo, a Constituição, têm a sua eficácia condicionada pelos fatos concretos da vida, não se afigura possível que a interpretação faça deles tábula rasa. Ela há de contemplar essas condicionantes, correlacionando-as com as proposições normativas da Constituição.

Para cada caso concreto, se faz necessário a construção de norma jurídica que satisfaça as especificidades do direito material que se pleiteia, em consonância com os direitos e garantias fundamentais dos cidadãos, no caminho da efetivação democrática, sob a ótica substancial. Sendo a criação dessa norma "corolário da atividade hermenêutica". (SAMPAIO JÚNIOR, 2011, p. 408)

Para tanto, o Judiciário, em especial o STF, irá se valer de técnicas de interpretação, como ponderação e otimização e princípios de interpretação, tais como 0 da proporcionalidade e da interpretação conforme a Constituição. ${ }^{11}$

Os métodos aplicados para interpretação das leis infraconstitucionais não são suficientes para a interpretação da norma constitucional, isso pela elevada complexidade que a Constituição apresenta em seu sistema de unidade impregnado de princípios e valores.

A Constituição tem o seu conteúdo revestido por caráter político, motivo pelo qual a interpretação de suas normas se distancia dos métodos utilizados para a determinação do sentido e do alcance das demais normas jurídicas, “cuja interpretação se move num círculo menos sujeito a incertezas e dificuldades como aquelas que aparecem tocante à norma constitucional”. (BONAVIDES, 2008, p. 130)

O caminho da hermenêutica constitucional, portanto, é complexo, mas precisa ser percorrido com fim de concretizar os direitos fundamentais. Os direitos fundamentais não podem ficar esperando a vontade do Legislativo, nem do Executivo. É necessário que o

${ }^{11}$ Vários outros princípios e outras técnicas de interpretação são enumerados pela doutrina, tais como força normativa da Constituição (que já foi estudado neste trabalho), unidade da Constituição, filtragem constitucional (que já foi mencionada neste estudo). Todavia desborda do propósito deste trabalho adentrar no estudo destas técnicas e princípios.

Versão em português recebida em 08/08/2014, aceita em 29/12/2014, e autorizada para publicação em $29 / 06 / 2015$ 
Judiciário, nos limites que a Constituição determina, possa suprir o déficit democrático da ineficácia constitucional.

O Poder Judiciário, dessa forma, cria o direito no caso concreto, pois que, segundo Ávila (2008, p. 33), “o intérprete não só constrói, mas reconstrói sentido, tendo em vista a existência de significados incorporados ao uso lingüístico e construídos na comunidade do discurso." Ressaltando que essa criação jurídica pela via hermenêutica é legítima e democrática, se estiver em consonância com a Constituição e em busca da realização dos direitos fundamentais.

\subsection{JUDICIALIZAÇÃO DA POLÍTICA}

Conforme Barroso (2011, p. 228-229), a “judicialização significa que questões relevantes do ponto de vista político, social ou moral estão sendo decididas, em caráter final, pelo Poder Judiciário.” Já De Paula (2011, p. 294), afirma que a “judicialização da política é uma atitude deliberada das próprias instâncias políticas em levar ao judiciário questões não resolvidas consensualmente nos parlamentos para mais uma rodada de decisão".

Com o neoconstitucionalismo, a defesa por uma maior atuação do Poder Judiciário em questões de cunho moral e político se mostra mais e mais patente, o que leva à judicialização da política e à idéia de ativismo judicial no campo constitucional.

A imprescindível proteção dos direitos fundamentais e da vontade da Constituição fez com que o Poder Judiciário passasse a decidir casos que, mesmo sendo de essência política, ficaram no esquecimento do Poder Legislativo e do Poder Executivo.

A propósito, e não se pretendendo esgotar os exemplos, ${ }^{12}$ já que há vários outros, observe-se alguns casos que configuram a judicialização da política e requerem uma atuação mais ativa no exercício da jurisdição constitucional: pesquisas com células-tronco embrionárias; ${ }^{13}$ limitações ao uso de algemas $;{ }^{14}$ vedação do nepotismo a todos os Poderes

\footnotetext{
12 "De fato, somente no ano de 2008, foram decididas pelo Supremo Tribunal Federal, no âmbito de ações diretas - que compreendem a ação direta de inconstitucionalidade (ADIn), a ação declaratória de constitucionalidade (ADC) e a argüição de descumprimento de preceito fundamental (ADPF) - questões como: a) o pedido de declaração de inconstitucionalidade, pelo Procurador-Geral da República, do art. $5^{\circ}$ da Lei de Biossegurança, que permitiu e disciplinou as pesquisas com células-tronco embrionárias (ADIn 3.150); (ii) o pedido de declaração da constitucionalidade da Resolução $\mathrm{n}^{\circ} 7$, de 2006, do Conselho Nacional de Justiça, que vedou o nepotismo no âmbito do Poder Judiciário (ADC 12); (iii) o pedido de suspensão dos dispositivos da Lei de Imprensa incompatíveis com a Constituição de 1988 (ADPF 130). No âmbito das ações individuais, a Corte se manifestou sobre temas como quebra de sigilo judicial por CPI, demarcação de terras indígenas na região conhecida como Raposa/Serra do Sol e uso de algemas, dentre milhares de outros.” (BARROSO, 2009, p. 4)

${ }^{13}$ ADI 3510/DF. STF, Relator Ministro Carlos Ayres Brito.

Versão em português recebida em 08/08/2014, aceita em 29/12/2014, e autorizada para publicação em $29 / 06 / 2015$
} 
públicos; ${ }^{15}$ união entre pessoas do mesmo sexo; ${ }^{16}$ interrupção de gestação de feto anencéfalo. $^{17}$

A judicialização da política, no Estado brasileiro, ganhou grandes proporções, devido à abrangente e à analítica constitucionalização e à sistemática do controle de constitucionalidade que vigora no país, em que se permite a qualquer juiz ou tribunal exercer o controle no caso concreto (controle difuso de constitucionalidade - modelo norteamericano) e o amplo acesso ao Supremo Tribunal Federal, no controle concentrado (controle concentrado de constitucionalidade - modelo europeu) por meio das ações diretas. (BARROSO, 2011, p. 230-231)

Conforme De Paula (2011, p. 302), o controle de constitucionalidade, "em seu sentido forte," em que caiba ao Poder Judiciário a última palavra a respeito de ser ou não juridicamente legítima certa medida política que instâncias representativas tomem, expressa, no prisma político, "a última trincheira para que as minorias vejam seus interesses alcançados, entre os quais o de que uma decisão majoritária não valha, sucumbindo aos limites do texto constitucional".

Segundo Cittadino (2002, p. 136),

\begin{abstract}
Esse processo de ampliação da ação judicial pode ser analisado à luz das mais diversas perspectivas: o fenômeno da normatização de direitos, especialmente em face de sua natureza coletiva e difusa; as transições pós-autoritárias e a edição de constituições democráticas - seja em países europeus ou latino-americanos - e a consequente preocupação com o reforço das instituições de garantia do estado de direito, dentre elas a magistratura e o Ministério Público; as diversas investigações voltadas para a elucidação dos casos de corrupção a envolver a classe política, fenômeno já descrito como "criminalização da responsabilidade política"; as discussões sobre a instituição de algum tipo de poder judicial internacional ou transnacional, a exemplo do tribunal penal internacional; e, finalmente, a emergência de discursos acadêmicos e doutrinários, vinculados à cultura jurídica, que defendem uma relação de compromisso entre Poder Judiciário e soberania popular. Se considerarmos qualquer uma dessas chaves interpretativas, podemos compreender porque a expansão do poder judicial é vista como um reforço da lógica democrática. Com efeito, seja nos países centrais, seja nos países periféricos, na origem da expansão do poder dos tribunais, percebe-se uma mobilização política da sociedade. Não é por outra razão que esse vínculo entre democracia e ativismo judicial vem sendo designado como "judicialização da política".
\end{abstract}

${ }^{14}$ Súmula Vinculante $\mathrm{n}^{\circ} 11$ do STF. "Só é lícito o uso de algemas em casos de resistência e de fundado receio de fuga ou de perigo à integridade física própria ou alheia, por parte do preso ou de terceiros, justificada a excepcionalidade por escrito, sob pena de responsabilidade disciplinar, civil e penal do agente ou da autoridade e de nulidade da prisão ou do ato processual a que se refere, sem prejuízo da responsabilidade civil do Estado."

${ }^{15}$ ADC 12 do STF, Relator Ministro Carlos Ayres Brito e Súmula Vinculante nº 13/2008 do STF.

${ }^{16}$ ADI 4277 e ADPF 132, ambas do STF e com relator Ministro Carlos Ayres Brito.

${ }^{17}$ ADPF $n^{\circ}$ 54. Relator Ministro Marco Aurélio. O STF, no dia 12 de abril de 2012, decidiu, por maioria dos votos, que não é crime a interrupção da gravidez, em caso de anencefalia.

Versão em português recebida em 08/08/2014, aceita em 29/12/2014, e autorizada para publicação em $29 / 06 / 2015$ 
Dessa forma, a judicialização da política faz parte do próprio processo democrático, pois que constitui mecanismo de concretização de direitos fundamentais pelo Poder Judiciário, quando forem eles sonegados, quer seja pelo Poder Executivo, quer seja pelo Poder Legislativo.

A resposta à sociedade deve ser dada, como pressuposto lógico do Estado Democrático de Direito, de maneira que, o redimensionamento do olhar constitucional para os direitos fundamentais deve exigir do Estado o cumprimento destes direitos. Dessa forma, a atuação do Poder Judiciário para concretização de direitos quando da omissão dos demais Poderes, mesmo em âmbito político, é louvável e harmonicamente democrática.

A relação do Poder Judiciário com as políticas públicas não significa dizer, entretanto, que deva este Poder criar tais políticas, o que desbordaria do propósito de ser da estrutura organizacional do Estado Democrático de Direito. O papel do Judiciário, nesse mister, é determinar que as mesmas sejam cumpridas.

Como explica Capilongo (1994, p. 118), relacionando o Judiciário e a democracia no Brasil, hodiernamente, "setores antes desorganizados e pouco sensíveis à utilização do Direito enquanto ferramenta de conquista e ampliação da cidadania política (...) passam a encarar o Judiciário como um espaço relevante de luta política". ${ }^{18}$

As determinações constitucionais necessitam ser cumpridas. Os direitos sociais e culturais, por exemplo, precisam de políticas públicas para implementação, de forma que a igualdade material se concretize, em relutância ao processo de segregação social. É dizer, é imprescindível a atuação do Estado, visando assegurar a realização dos direitos fundamentais e a vontade da Constituição, de forma que a omissão do Executivo e do Legislativo dá azo para que o cidadão procure o Poder Judiciário como modo de exercício da democracia. E o Judiciário, uma vez provocado, precisa decidir.

Por conseguinte, nota-se que a judicialização da política é reflexo do desenho constitucional, que permite "que discussões de largo alcance político e moral sejam trazidas sob a forma de ações judiciais. Vale dizer: a judicialização não decorre da vontade do Judiciário, mas sim do constituinte”. (BARROSO, 2009, p. 13-14)

\footnotetext{
${ }^{18}$ Capilongo (1994, p. 118-119) continua a explanação: "Dito de outro modo: além de continuar resguardando valores tradicionalmente garantidos pela técnica jurídica, o Judiciário vive o dilema de adaptar seu repertório a situações inéditas. Essas situações, protagonizadas por grupos há pouco tempo alijados do acesso à Justiça e, muitas vezes, orientados por uma racionalidade dificilmente amoldável às rotinas judiciais, vêm, lenta mas progressivamente, desafiando a rigidez lógico-formal dos sistemas legais. A partir disso é possível compreender, por exemplo, a práxis 'alternativa' e 'libertadora' de magistrados que, por dever funcional, procuram oferecer respostas a essas demandas".

Versão em português recebida em 08/08/2014, aceita em 29/12/2014, e autorizada para publicação em 29/06/2015
} 


\subsection{ATIVISMO JUDICIAL E O PROTAGONISMO DO JUDICIÁRIO}

Sobre o ativismo judicial, explica Barroso (2011, p. 233) que, expurgada a conotação depreciativa imputada à expressão, equiparando-a à ação inapropriada do Poder Judiciário:

(...) a ideia de ativismo judicial está associada a uma participação mais ampla e intensa do Judiciário na concretização dos valores e fins constitucionais, com maior interferência no espaço de atuação dos outros dois Poderes. Em muitas situações, sequer há confronto, mas mera ocupação de espaços vazios.

De Paula (2011, p. 294), por sua vez, anota que "parece haver certo consenso no sentido de que o ativismo judicial é uma prática dos tribunais que ocorre à revelia ou com a inércia dos outros poderes constituídos”. É quando o Poder Legislativo se retrai, obstando a efetivação das demandas sociais, que normalmente se instala o ativismo. (BARROSO, 2009, p. 5)

Assevera Barroso (2009, p. 5) que diversas condutas fazem manifestar essa postura ativista, nas quais estão inclusas:

(i) a aplicação direta da Constituição a situações não expressamente contempladas em seu texto e independentemente de manifestação do legislador ordinário; (ii) a declaração de inconstitucionalidade de atos normativos emanados do legislador, com base em critérios menos rígidos que os de patente e ostensiva violação da Constituição; (iii) a imposição de condutas ou de abstenções ao Poder Público, notadamente em matéria de políticas públicas.

Para ilustrar o ativismo pela aplicação direta da Constituição, em situações que não estejam expressamente contempladas no texto constitucional e independente de manifestação do Legislativo, pode ser mencionado o caso da fidelidade partidária. Aqui, o STF construiu uma nova proposição de perda de mandato parlamentar, diversa das que se encontram previstas de forma expressa na Constituição, pois, em razão do princípio democrático, declarou que a vaga no Congresso não pertence ao político eleito, mas sim ao partido político ao qual esse político pertença. (BARROSO, 2009, p. 6)

Outro exemplo de mesma natureza é a extensão da vedação do nepotismo a todos os Poderes do Estado, em que o STF editou a súmula vinculante $\mathrm{n}^{\mathrm{o}} 13,{ }^{19}$ após julgar um único

\footnotetext{
${ }^{19}$ Súmula Vinculante no 13 do STF: “A nomeação de cônjuge, companheiro, ou parente, em linha reta, colateral ou por afinidade, até o $3^{\circ}$ grau, inclusive, da autoridade nomeante ou de servidor da mesma pessoa jurídica, investido em cargo de direção, chefia ou assessoramento, para o exercício de cargo em comissão ou de Versão em português recebida em 08/08/2014, aceita em 29/12/2014, e autorizada para publicação em $29 / 06 / 2015$
} 
caso (BARROSO, 2009, p. 6). O Supremo considerou a prática do nepotismo ofensiva aos princípios da moralidade e impessoalidade, além dos da eficiência e igualdade, ao apreciar a constitucionalidade da Resolução ${ }^{20} \mathrm{n}^{\mathrm{o}} 07$ de 2005 do Conselho Nacional de Justiça que vedava a prática de nepotismo nos órgãos jurisdicionais. (DE PAULA, 2011, p. 289)

Como exemplo de declaração de inconstitucionalidade, com base em critérios menos rígidos que os de patente e ostensiva violação constitucional, de atos normativos produzidos pelo Congresso Nacional, Barroso (2009, p. 6-7) lembra que

O STF declarou a inconstitucionalidade da aplicação das novas regras sobre coligações eleitorais à eleição que se realizaria em menos de uma ano (sic) da sua aprovação. Para tanto, precisou exercer a competência - incomum na maior parte das democracias - de declarar a inconstitucionalidade de uma emenda constitucional, dando à regra da anterioridade anual da lei eleitoral $(\mathrm{CF}$, art. 16) o status de cláusula pétrea. ${ }^{21}$

No que concerne ao ativismo em que o Judiciário impõe determinada conduta ou abstenção ao Poder Público, notadamente quando se trata de políticas públicas, pode-se mencionar como exemplo a "distribuição de medicamentos e determinação de terapias mediante decisão judicial”. (BARROSO, 2009, p. 7) ${ }^{22}$

Outros exemplos emblemáticos que refletem a judicialização da política e o ativismo judicial, sem a pretensão de esgotá-los, como já lembrado no tópico anterior, são pesquisas com células-tronco embrionárias; ${ }^{23}$ limitações ao uso de algemas; ${ }^{24}$ união entre pessoas do mesmo sexo, ${ }^{25}$ interrupção de gestação de feto anencéfalo. ${ }^{26}$

confiança, ou, ainda, de função gratificada na Administração Pública direta e indireta, em qualquer dos Poderes da União, dos Estados, do Distrito Federal e dos Municípios, compreendido o ajuste mediante designações recíprocas, viola a Constituição Federal".

${ }^{20}$ Foi por meio da ADC $n^{\circ} 12$ que o STF declarou constitucional a resolução $n^{\circ} 07$ de 2005 do Conselho Nacional de Justiça - CNJ. Barroso (2009, p. 19) lembra que na seqüência do julgamento dessa ADC, o STF “ao julgar recurso extraordinário oriundo do Rio Grande do Norte, no qual se discutia a validade da nomeação de parentes de vereador e de vice-prefeito para cargos públicos, o Tribunal estendeu a vedação do nepotismo aos Poderes Executivo e Legislativo, aprovando a Súmula de n 13”.

${ }^{21} \mathrm{O}$ autor faz análise da ADIN 3658.

${ }^{22}$ Nesse sentido, observa-se julgado do STF no tocante ao fornecimento de medicamento a paciente com HIV/AIDS: "O direito à saúde - além de qualificar-se como direito fundamental que assiste a todas as pessoas representa conseqüência constitucional indissociável do direito à vida. O Poder Público, qualquer que seja a esfera institucional de sua atuação no plano da organização federativa brasileira, não pode mostrar-se indiferente ao problema da saúde da população, sob pena de incidir, ainda que por censurável omissão, em grave comportamento inconstitucional" (AgRgRE 271.286-RS, 2a T., j. 12.09.2000, rel. Min. Celso de Mello, DJU 24.11.2000, vol.101). (CAMBI, 2009, p. 242-243).

${ }^{23}$ ADI 3510/DF. STF, Relator Ministro Carlos Ayres Brito.

${ }^{24}$ Súmula Vinculante $\mathrm{n}^{\circ} 11$ do STF.

${ }^{25}$ ADI 4277 e ADPF 132, ambas do STF e com relator Ministro Carlos Ayres Brito.

${ }^{26}$ ADPF $n^{\circ}$ 54. Relator Ministro Marco Aurélio.

Versão em português recebida em 08/08/2014, aceita em 29/12/2014, e autorizada para publicação em $29 / 06 / 2015$ 
Ressalta-se, por necessário, que essa ampliação no exercício da jurisdição constitucional, não quer significar invasão indevida do Judiciário na esfera de atuação dos demais Poderes, o que configuraria afronta à tripartição de poderes e ao princípio democrático. Até porque, resulta, lógica e naturalmente, de uma nova forma de se perceber a jurisdição exercida nesse novo cenário do Estado Constitucional Democrático de Direito, “em que os pilares fundamentais do texto constitucional precisam restar satisfeitos em todas as situações fáticas, logo, o Poder Judiciário não pode fugir de tal missão de concretização dos valores constitucionais”. (SAMPAIO JÚNIOR, 2011, p. 422)

Conforme Branco (2011, p. 393-395), o Ministro Celso de Mello, na revista anuário do judiciário de 2010 sustentou que

(...) o chamado ativismo judicial é uma resposta do Supremo a provocações formais da sociedade a partir de mecanismos criados pela Constituição para neutralizar o caráter lesivo das omissões do Congresso ou do Executivo. Nesses casos, não há interferência indevida do Supremo: o Tribunal está apenas cumprindo sua função.

Nessa perspectiva, esse protagonismo do Poder Judiciário, em primazia do Supremo Tribunal Federal, reflete a busca pela concretização dos direitos fundamentais e da realização da vontade constitucional, impedidos de satisfação em virtude das omissões estatais - pelo Executivo e pelo Judiciário.

O ativismo judicial não se confunde com arbitrariedade, tampouco com violação ao princípio da tripartição dos poderes e ao princípio democrático. Isso fica claro ao se perceber que a atuação da jurisdição constitucional não se efetiva exclusivamente por vontade do órgão jurisdicional. O Poder Judiciário segue o mandamento constitucional da inércia, determinando esse princípio que a atuação do Judiciário, no exercício da jurisdição, só será exercida quando for ele provocado.

Uma vez provocado, o órgão judicial, necessariamente, deverá analisar o caso, conforme determina o princípio da inafastabilidade do Judiciário, o que representa direito fundamental do acesso à justiça, nos termos do art. $5^{\circ}, \mathrm{XXXV}$ da Constituição Federal $-\mathrm{CF}^{27}$

Nesse sentido, Cambi anota que “a intervenção do Judiciário não é ampla e incondicionada. Depende da prévia verificação da violação dos direitos fundamentais". Ocorrendo isso, continua a explicar o autor, o Poder Judiciário não pode se esquivar da tutela desses direitos fundamentais, de maneira que, estando "dentro dos parâmetros estabelecidos pela argumentação jurídica, sempre mediante decisões motivadas voltadas à legitimação do

\footnotetext{
${ }^{27}$ Art. 5 $5^{\circ}$ XXV, CF - "a lei não excluirá da apreciação do Poder Judiciário lesão ou ameaça a direito." Versão em português recebida em 08/08/2014, aceita em 29/12/2014, e autorizada para publicação em 29/06/2015
} 
poder jurisdicional, o protagonismo judiciário, assim compreendido, justifica-se". (CAMBI, 2009, p. 247)

Se a sociedade evolui, tornando-se mais complexa e mais técnica, as prestações sociais passam a ser exigidas pelos cidadãos na complexidade social que os cercam. Conseqüentemente, uma nova forma de pensar, pautada numa pluralidade social, faz com que os cidadãos queiram, cada vez mais, participar do processo político e democrático.

Isso implica na busca incessante pela satisfação de seus direitos e pelo cumprimento da democracia e da Constituição. Os grupos sociais se expandem, formando blocos de resistência ao descaso do Estado para com a sociedade. "Mudaram-se os parâmetros de ordem e de justiça". Nessa senda, nota-se que "parece existir, por enquanto, uma via de mão dupla na relação entre o Judiciário e o cidadão. O cidadão deposita no Judiciário a confiança que perdeu nos outros poderes. E os magistrados dão guarida às pretensões dos que buscam os tribunais". (CAPILONGO, 1994, p. 121)

O que não se pode aceitar, portanto, é uma atuação jurisdicional, que venha a desbordar dos limiares impostos pela própria Constituição, ou seja, caminhar as trilhas criadas e permitidas pela Constituição é o que pode fazer o julgador hermeneuta. Logo, valendo-se dos métodos de hermenêutica, irá o exegeta dizer a vontade da Constituição, prestando a tutela jurisdicional, complementando o processo democrático e contribuindo para a construção e consolidação do Estado constitucional democrático de direito.

\section{DAS CONSIDERAÇÕES FINAIS}

O Estado Democrático de Direito emerge como representante da mudança de comportamento da sociedade e do Estado, na busca pela concretização dos direitos fundamentais como fundamento da democracia e da dignidade humana.

Observou-se, então, que a sociedade passa a ter uma posição ativa, exigindo do Estado o implemento das prestações sociais por ele assumidas, o que se coaduna com a própria noção de realização da Constituição. Além disso, foi possível perceber um novo papel para o Poder Judiciário, que passou a ter mecanismos de atuação, pela via jurisdicional, para exigir do Estado o cumprimento das políticas públicas, em consonância com um pensar constitucionalista.

As idéias de um novo constitucionalismo, ou neoconstitucionalismo, vão intensificar mais e mais essa atuação do Judiciário. Isso porque há uma mudança de paradigma, na qual a 
Constituição passa a ser reconhecida como norma, a ter força normativa, passando ela a exigir o seu cumprimento em todos os poderes e esferas do Estado.

É nesse contexto de expansão da jurisdição, principalmente a constitucional, que se englobam as discussões sobre ativismo judicial e judicialização da política, no prisma da principiologia constitucional e da democracia.

Com essa nova forma de se perceber a Constituição, no centro do ordenamento jurídico, havendo um processo de constitucionalização do direito e das leis infraconstitucionais que vai exigir uma filtragem constitucional, a jurisdição constitucional dá ao Poder Judiciário um papel de destaque no desenho institucional do Estado.

Para tanto, faz-se necessário um amplo controle de constitucionalidade, que não se resuma a aferir a compatibilidade da norma infraconstitucional com a Constituição, mas se estenda, na conformação democrática, de forma a superar a omissão dos Poderes Executivo e Legislativo, para proporcionar a concretização dos direitos fundamentais.

Dessa forma, a teoria da tripartição de poderes precisa ser revista, para que se possa aplicá-la em conformidade com a realidade social que se apresenta. Não há que se falar em afronta a esse princípio, quando o Judiciário realiza decisões de cunho político, criando norma no caso concreto, e impondo, ao Estado, o cumprimento de políticas públicas, pois consiste em uma requisição democrática para consecução dos direitos fundamentais assegurados constitucionalmente.

As novas técnicas hermenêuticas permitem, portanto, que a jurisdição constitucional seja exercida da forma mais desejada pela Constituição. Por isso, quando o juiz decidir, ele precisará dar um sentido à norma, sem, contudo, desbordar dos limites constitucionais, sob pena de se tornar arbitrário. Logo, o juiz cria direito no caso concreto para realizar a vontade da Constituição, o que se coaduna com o cumprimento dos direitos fundamentais. É essa a visão que faz do ativismo judicial uma fonte de realização democrática.

\section{REFERÊNCIAS}

AGRA, Walber de Moura. Neoconstitucionalismo e superação do positivismo. In: DIMOULIS, Dimitri e DUARTE, Écio Oto (coord.) Teoria do direito neoconstitucional: superação ou reconstrução do positivismo jurídico? São Paulo: Método, 2008.

ÁVILA, Humberto. Teoria dos princípios da definição à aplicação dos princípios jurídicos. $8^{\circ}$ ed. São Paulo: Malheiros, 2008.

BARACHO, José Alfredo de Oliveira. Jurisdição constitucional da liberdade. In: SAMPAIO, José Adércio Leite (org.). Jurisdição constitucional e direitos fundamentais. Belo Horizonte: Del Rey, 2003.

Versão em português recebida em 08/08/2014, aceita em 29/12/2014, e autorizada para publicação em 29/06/2015 
BARROSO, Luis Roberto. Constituição, democracia e supremacia judicial: direito e política no Brasil contemporâneo. In: PAULA, Daniel Giotti de; FELLET, André Luiz Fernandes; NOVELINO, Marcelo (orgs.). As novas faces do ativismo judicial. Salvador: JusPodivm, 2011.

Judicialização, ativismo judicial e legitimidade democrática. 2009. Disponível em: <http://www.migalhas.com.br/arquivo_artigo/art20090130-01.pdf>. Acesso em: 21 jan. 2012.

Neoconstitucionalismo e constitucionalização do direito (o triunfo tardio do direito constitucional no Brasil). Revista eletrônica sobre a reforma do Estado (RERE), Salvador, Instituto Brasileiro de Direito Público, $\mathrm{n}^{\circ}$. 9, mar/abr/mai, 2007. Disponível em: <HTTP://direitodoestado.com.br/rere.asp>. Acesso em: 22 set. 2011.

BASTOS, Celso Ribeiro. Hermenêutica e interpretação constitucional. $3^{\circ}$ ed. São Paulo: Celso Bastos editor, 2002.

BONAVIDES, Paulo. Curso de direito constitucional. 23º ed. São Paulo: Malheiros, 2008. BRANCO, Paulo Gustavo Gonet. Em busca de um conceito fugidio - o ativismo judicial. In: DE PAULA, Daniel Giotti; FELLET, André Luiz Fernandes; NOVELINO, Marcelo (orgs.). As novas faces do ativismo judicial. Salvador: JusPodivm, 2011.

BULOS, Uadi Lammêgo. Curso de direito constitucional. $4^{\circ}$ ed. São Paulo: Saraiva, 2009.

CAMBI, Eduardo. Neoconstitucionalismo e neoprocessualismo. Direitos fundamentais, políticas públicas e protagonismo do judiciário. São Paulo: Revista dos tribunais, 2009.

CAPILONGO, Celso Fernandes. O judiciário e a democracia no Brasil. Revista USP. 1994. Disponível em <http://www.usp.br/revistausp/21/10-celso.pdf>. Acesso em: 20 jan. 2012.

CITTADINO, Gisele. Poder Judiciário, ativismo judicial e democracia. Revista da Faculdade de Direito de Campos, Campos dos Goytacazes, RJ, v. 2/3, n. 2/3, p. 135-144, 2001-2002. Disponível em: <http://bdjur.stj.jus.br/dspace/handle/2011/25512>. Acesso em: 20 jan. 2012.

DE PAULA, Daniel Giotti. Ainda existe separação de poderes? A invasão da política pelo direito no contexto do ativismo judicial e da judicialização da política. In: DE PAULA, Daniel Giotti; FELLET, André Luiz Fernandes; NOVELINO, Marcelo (orgs.). As novas faces do ativismo judicial. Salvador: JusPodivm, 2011.

DIMOULIS, Dimitri e DUARTE, Écio Oto (coord.) Teoria do direito neoconstitucional: superação ou reconstrução do positivismo jurídico? São Paulo: Método, 2008.

FERREIRA FILHO, Manoel Gonçalves. A cultura dos direitos fundamentais. In: SAMPAIO, José Adércio Leite (org.). Jurisdição constitucional e direitos fundamentais. Belo Horizonte: Del Rey, 2003.

GARCIA-PELAYO, Manuel. Derecho constitucional comparado. $4^{\circ}$ ed. Madri: Revista de Ocidente, S.A., 1957.

HESSE, Konrad. A força normativa da constituição. Tradução de Gilmar Ferreira Mendes. Porto Alegre: Sérgio Antônio Fabris Editor, 1991.

JUSTEN FILHO, Marçal. O direito das agências reguladoras independentes. São Paulo: Dialéctica, 2002.

MARINONI, Luiz Guilherme. Curso de processo civil. $2^{\circ}$. ed. São Paulo: Revista dos Tribunais, 2007. V.I.

MENDES, Gilmar Ferreira. Direitos fundamentais e controle de constitucionalidade. $2^{\circ}$ ed. São Paulo: Celso Bastos editor: Instituto Brasileiro de Direito Constitucional, 1999.

MONCADA, Luís S. Cabral de. Ensaio sobre a lei. Coimbra: Coimbra Editora, 2002.

PEREIRA, Rodolfo Viana. Hermenêutica filosófica e constitucional. $2^{\circ}$ ed. Belo Horizonte: Del Rey, 2006.

SAMPAIO JÚNIOR, José Herval. Ativismo judicial: autoritarismo ou cumprimento dos deveres constitucionais? In: DE PAULA, Daniel Giotti; FELLET, André Luiz Fernandes;

Versão em português recebida em 08/08/2014, aceita em 29/12/2014, e autorizada para publicação em 29/06/2015 
NOVELINO, Marcelo (orgs.). As novas faces do ativismo judicial. Salvador: JusPodivm, 2011.

SARMENTO, Daniel. A dimensão objetiva dos direitos fundamentais: fragmentos de uma teoria. In SAMPAIO, José Adércio Leite (org.). Jurisdição constitucional e direitos fundamentais. Belo Horizonte: Del Rey, 2003.

O neoconstitucionalismo no Brasil: riscos e possibilidades. In: DE PAULA, Daniel Giotti de; FELLET, André Luiz Fernandes; NOVELINO, Marcelo (orgs.). As novas faces do ativismo judicial. Salvador: JusPodivm: 2011.

STRECK, Lenio Luiz. A resposta hermenêutica à discricionariedade positivista em tempos de pós-positivismo. In: DIMOULIS, Dimitri e DUARTE, Écio Oto (coord.) Teoria do direito neoconstitucional: superação ou reconstrução do positivismo jurídico? São Paulo: Método, 2008.

Hemenêutica jurídica $\mathbf{e}(\mathrm{m})$ crise. Uma exploração hermenêutica da construção do direito. $8^{\circ}$ ed. Porto Alegre: Livraria do advogado, 2009. 